\title{
Curriculum Integration versus Educating for Global Citizenship: A (Disciplinary) View from the International Relations Classroom
}

\section{Dennis R. Gordon}

Santa Clara University

Instead of bragging about the number of students going abroad and hosting of international fee paying students, the number of courses in English and the abstract claim of making students global citizens, we want to focus on learning outcomes. How can we make sure that students receive the right learning outcomes that make them ready for a world that is more and more interculturally and internationally connected? What does that mean for faculty development? What are the implications for the assessment of students? How can instruments such as study abroad, international classrooms, teaching in another language, recruitment of international students and cross-border delivery, contribute to that process?

Uwe Brandenburg and Hans de Wit, The Guardian, April 2012

I would argue strongly that the most fruitful education for the globe will be. . one that is not merely technical or appreciative but genuinely "liberating" or "emancipatory" by virtue of cultivating critical thought, self-reflection, and a sense of social responsibility. . . . international educators will establish an intellectual and philosophical standpoint of their own that transcends the homeland perspective and can provide academic guidance for student experience overseas ... making peace and justice issues an aspect of all overseas study.

Theodore E. Long, "From Study Abroad to Global Studies"

As these two quotations show, the study abroad profession continues to find itself in an epistemological and ontological debate over the purpose of students having an overseas educational experience. Brandenburg and de Wit ask "how can we make sure students receive the right outcomes" and Long replies that international educators should create a new global curriculum distinct from what is taught on the home campus. Long, in positing the existence of "a world system of societies beyond the national society" refreshes the ongoing debate in study abroad circles about globalization, global citizenship, and a set of normative assumptions about the purpose of higher education. Long's description of the international system, thoroughly engaging as it may be, is one that many social scientists and most International Relations scholars would not recognize. Indeed, his call for the creation of a self-sustaining, stand-alone pedagogy and curriculum to transform study abroad to global studies, might well further alienate many faculty in the United States and elsewhere. This paper offers a view from the classroom and departmental chair's office, using the teaching of introductory International Relations and some basic theoretical foundations of the field, Realism, Cosmopolitanism, and Constructivism, to explore how study abroad can balance calls to educate for 
global citizenship with the academic needs of students, faculty, and a society expecting a relevant higher education curriculum. While referring to Long's important and insightful essay, this paper is not intended to provide a comprehensive review and critique. The central point here is that curriculum integration of the overseas experience with what is offered on the home campus, based on universally recognized academic disciplines and interdisciplinary methodologies and pedagogies, is what most students and educators seek from study abroad. As for the goal of a study abroad experience rooted in social justice and peace-making, if a rigorous discipline-based education is combined with the consciousness-raising experience of living in another culture, the "emancipatory" or "liberating" experience that Long calls for may well take care of itself.

\section{The Purpose of Study Abroad}

The claim of "educating for global citizenship" has come to symbolize what critics consider mission drift on the part of some study abroad programs. While such rhetoric can also be found in the general goals of most domestic institutions of higher learning in the United States, it seems all the more inappropriate when used by study abroad practitioners professing a deep understanding of how to send eager undergraduates out to learn the mysteries of the world. Theodore Long's description of a global society where "people from multiple homelands encounter situations where no one group can define who is legitimate, so global citizenship is claimed on the basis of common human rights, which purport to authorize anyone to participate in creating collective goods" (Long, 2013, p.32) would be dismissed by most International Relations scholars. Indeed, many would reply "tell that to the target of a drone strike in Pakistan or the family of a July 7 victim in London" who have had more than enough of external actors killing hundreds for real or imagined wrongdoings.

How is global citizenship manifested? If a global citizenry exists, based on international travel statistics, few are from the United States. Roughly 30\% of U.S. residents hold passports and 5\% go abroad each year, mostly to Mexico and Canada (Chalmers, 2012). As for college students, less than 300,000 of the 21,000,000 enrolled in post-secondary institutions study abroad (National Center for Education Statistics, 2012).

If not face-to-face contact, is it a global social media and consumer culture which is creating a global identity? It is easy for those who do not study human behavior at the state and inter-state level to assume that because people may have some electronic interactions with others around the world that a supra-national consciousness has emerged. It is one thing to recognize that news travels faster today, but quite another to assume that a global political consciousness and sovereign global institutions with the power to control and alter behavior exist or are on the horizon. Electronic interaction, moreover, is highly skewed towards the economically developed world. According to Internet World Stats, $75 \%$ of internet users were in the economically developed nations with only $7 \%$ taking part in Africa and 3\% in the Middle East. In other words, it is hard to say exactly who consciously populates the imagined globalized world, but most are comparatively well off. Certainly millions of others are affected by global forces today, just as they were when the international system was characterized by colonialism, imperialism, or interdependence but they hardly qualify as citizens 
with full political rights. What exactly is different about today's international system, if anything, is continuing academic work in progress.

As many observers have noted, the fundamental problem with imagined supra national communities is that no legal category of global citizen exists and that a study abroad student in post2009 economic meltdown Greece or Spain are more likely to encounter an anti-European Union demonstration than a celebration of Schuman's dream of a united Europe (Woolf, 2010). Secessionist movements, driven by nationalism not a quest for global citizenship, stretch from Scotland through Catalonia and on to the four corners of the earth. Mistrust of international governmental organizations, moreover, is almost a religion in the United States. An official from the Council on European Security and Cooperation, assigned poll-watching duties in the Lone Star State as part of the organization's mandate to monitor elections, was criticized in the local press for "messing with Texas" (interview, Dublin, 2012). Indeed, the closest thing to a global citizen might be someone awaiting trial at the International Criminal Court or a soldier serving in an out-gunned United Nations Peacekeeping force.

In exploring the curricular and normative rift over the ultimate goals of study abroad, it is important to remember that still less than $9 \%$ of college students in the United States have a study abroad experience, a small number given the acknowledged importance of international forces on the general public today. While there has been an increase in students from the natural sciences and engineering, $71 \%$ of participants are from the social sciences, humanities and business (Open Doors, 2013). There are, of course, a variety of reasons why participation is low with economic factors and family obligations playing a part. Should the profession be satisfied with this explanation or do concerns about academic focus and rigor of courses abroad also play a part? Is the problem that the study abroad experience is "largely derivative of their home curricula, not expressive of any coherent design that represents global education priorities (Long, 2013, p. 26)," or as Brandenburg and de Wit suggest, is it that many programs do not offer courses that meet students' specific academic needs? Has study abroad in some programs become far too general and focused on the experience with two few discipline-specific opportunities for today's career-minded students (and their parents)?

The call for a "genuinely global perspective that informs the development of . . . a coherent program of global studies" (Long, 2013, p26) has surfaced at a time when the goal of "educating for global citizenship" seems to be subsiding. Reasons for this shift include the continuing desire to foster intercultural competence and, the topic of this paper, curriculum integration. At the 2012 meeting of the Association for International Education Administrators, of 108 panel sessions only two used the term "global citizen" or "global citizenship." Instead, many focused on intercultural competence. Crucially, the term is intercultural not supra-cultural. It is a concept rooted in the recognition that humans still organize and/or inhabit discrete societies, cultures, movements for selfdetermination, and nation states.

Darla Deardorff, drawing upon her own research and that of other scholars, defines intercultural competence as both a specific set of skills and a life-long process and practice (Deardorff, 2006). A significant dimension of Deardorff's discussion is her qualification that “... beyond international 
education, what are the broader implications and contexts of intercultural competence?" In raising the normative dimension Deardorff foreshadows Long's call for a study abroad experience which fosters global citizenship and educates students "about the possibilities of sustaining peace and realizing human rights" (Long, 2013, p. 34). Indeed, if normative considerations are to be taken into account in higher education and study abroad, a crucial but seemingly obvious question must be asked, "intercultural competence towards what end?" While some definitions of intercultural competence contain normative goals, in general a culturally competent person is not necessarily a moral person. Indeed, learning language, local cultural norms, and empathy are hardly neutral and can be essential tools of the terrorist or sweat shop operator as well as the diplomat or aid worker.

Given some of the short-comings of the intercultural competence goal, at least for those who believe that normative considerations have a part in the classroom and co-curricular activities, the term "educating for global competence" has gained in popularity. Shari Becker Albright, chair of the Department of Education at Trinity University, adds a normative component to the pedagogic goals of international education:

-Knowledge of other world regions, cultures, and global/international issues -Skills in communicating in languages other than English, working in global or cross-cultural environments, and using information from different sources around the world -Values/perspectives of respect and concern for other cultures and peoples (Albright, 2012)

Albright's formulation complements Long's call for inclusion of normative goals in international education and study abroad. Still questions remain about how can study abroad educators respond to the multi-dimensional quest for disciplinary relevance, academic rigor, global competence, as well as the normative goals which lie behind study abroad mission statements and the home institution's values. A partial answer is suggested by a panel "Curriculum Integration: Re-inventing Ways to Harmonize European Courses within Their US Home Institutions" presented at a 2012 Forum on International Education Abroad conference in the Republic of Ireland. This panel's title begs the question; rather than re-inventing curriculum, why don't study abroad program designers consider revisiting existing curriculum and pedagogy offered by faculty in institutions around the globe? In years past, students simply walked into the overseas classroom and studied the disciplinary canon based on the professor's expertise and point of view. Their international education commenced with few preexisting expectations about immersion, service-learning, intercultural competency, or preparation for global citizenship. Most would agree that the students learned a fair amount in that setting, not the least of which was that different educational cultures and practices exist around the globe. Thus revisiting rather than re-inventing curriculum will lead to an appreciation that academic concepts, theories, methods, and curriculum already exist and are used every day at home and abroad. Acknowledging this legacy and storehouse of knowledge underscores the importance of wellconceived curriculum integration as study abroad in the United States comes under increasing scrutiny from academic assessment officers, budget managers, and faculty.

\section{The View from the International Relations Classroom}


Scholars in the field of International Relations employ a variety of theories, concepts, and the occasional buzz word to describe the historical path of cross-border interaction including colonialism, imperialism, neo-imperialism, dependency, interdependence, neo-interdependence, and the current coin of the realm, globalization. Globalization, while being over-utilized to the point of trivialization, does capture some of the technical and intellectual mobility which has increased political, economic, and cultural interaction in recent years. The study of International Relations, in large part, nonetheless maintains a state-centric focus and traditional questions about sovereignty, nationalism, conflict, cooperation, and multilateral regime-building.

The field of International Relations offers a good case study as it deals specifically with many of the global issues that study abroad proponents aim to address while providing a sophisticated analysis and discussion of how the world "really works." It is a discipline that students may be encouraged to study in preparation for an international experience. Most importantly, it is a field undergoing change as traditional theoretical perspectives such as Realism, Neo-Realism and Idealism are joined by Constructivism, Cosmopolitanism and other explanations, both new and old, analyzing what drives international behavior.

\section{Instructors' Views and Approaches}

As shown in the 2012 William and Mary TRIP survey of teaching, research, and policy views of International Relations instructors around the word, a slim plurality now identify with the Constructivist School:

Figure 1. TRIP Survey 2012

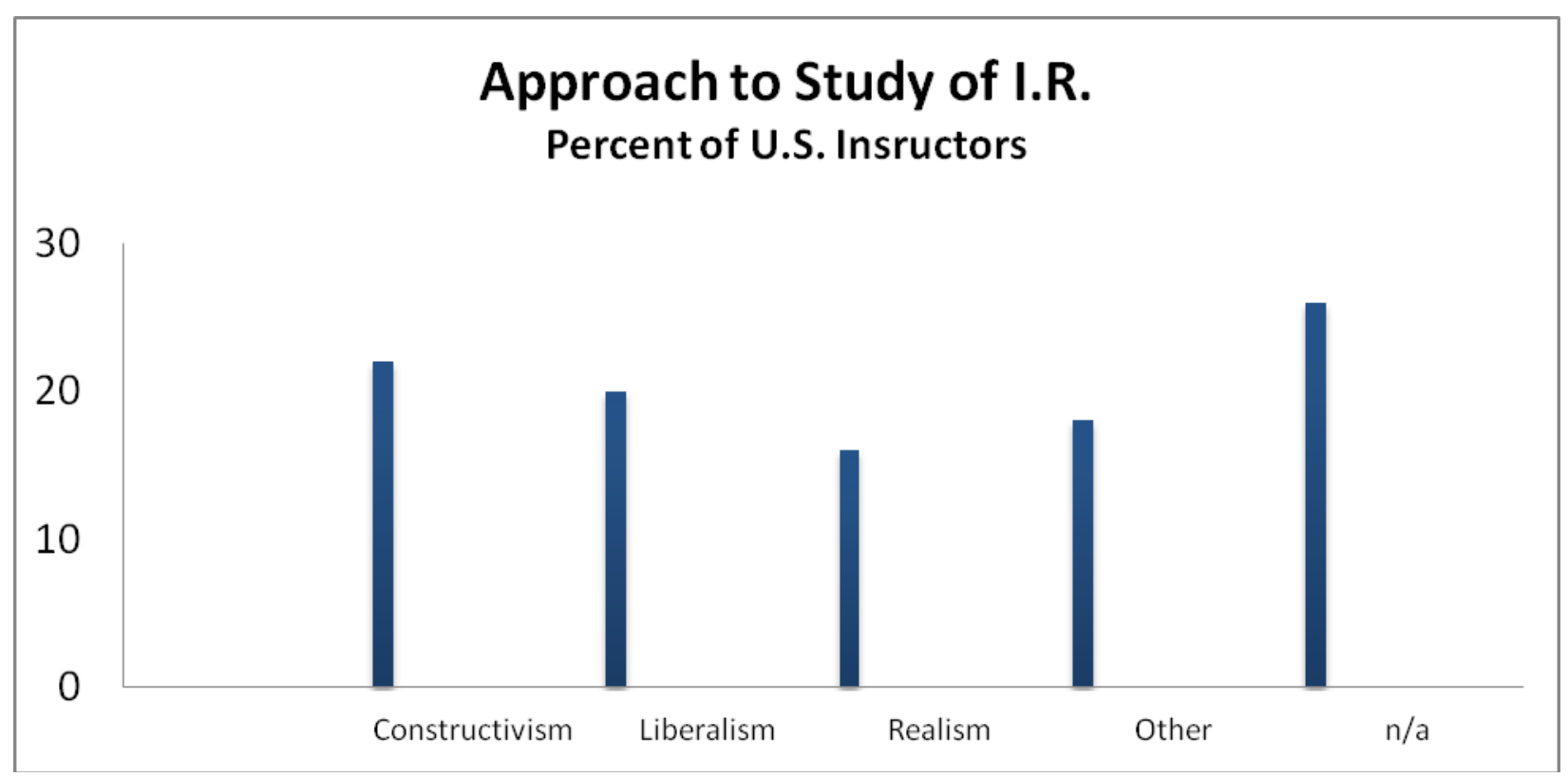


This same study reported that three scholars associated with the Constructivist perspective had produced "the best work in the field of IR in the last twenty years." Alexander Wendt topped the list, receiving mention by $24 \%$ of respondents (Maliniak, et al., 2012, p. 47).

Another significant trait of those who study International Relations is that, as shown in Figure 2, $80 \%$ of scholars in the United States indicate that they emphasize the role of ideational factors (such as culture, perceptions, ideology, or beliefs) when explaining behavior (Maliniak, et al. ,2012, p. 26). Rationality in this instance is broader and more nuanced that the general notion of selfinterest as power in the classic Realist framework and relates to the Constructivist emphasis on individual choice rather than the structure of the global political system.

Figure 2. TRIP Survey, 2012

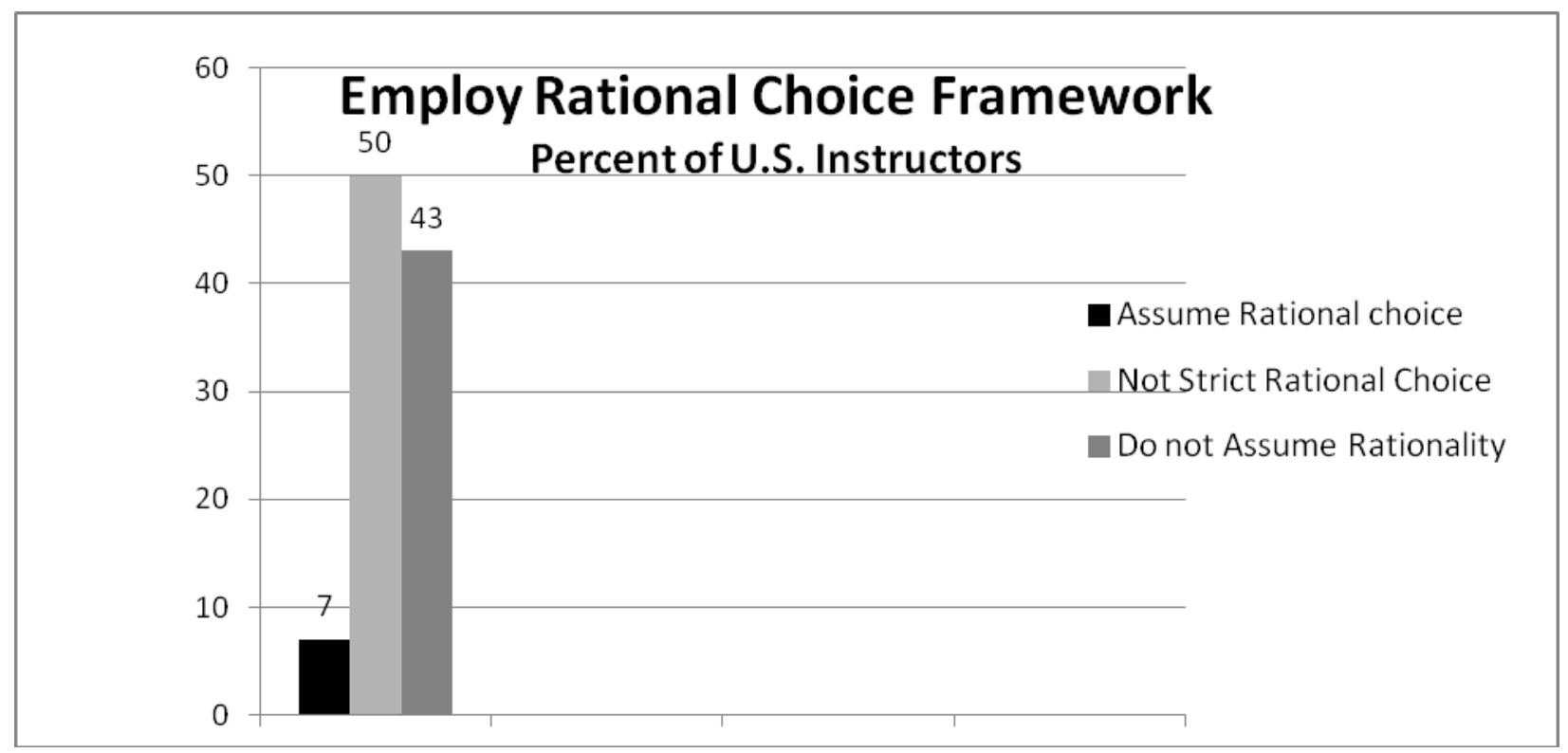

The TRIP Survey, as seen in Figure 3, found that the instructor's emphasis in the International Relations classroom is split almost evenly between scholarship and issues. The mixture of reviewing the paradigms that drive research with discussion of policy issues encourages students to question simplistic characterizations of global politics found in the media and public discourse. It also adds the applied policy dimension that many in study abroad value but retains the academic rigor that scholars expect. Mixing theory with practice, moreover, makes it more difficult for students to fall into the common pattern of romanticizing the study abroad host state and defining the causes of 
Figure 3. TRIP Survey 2012

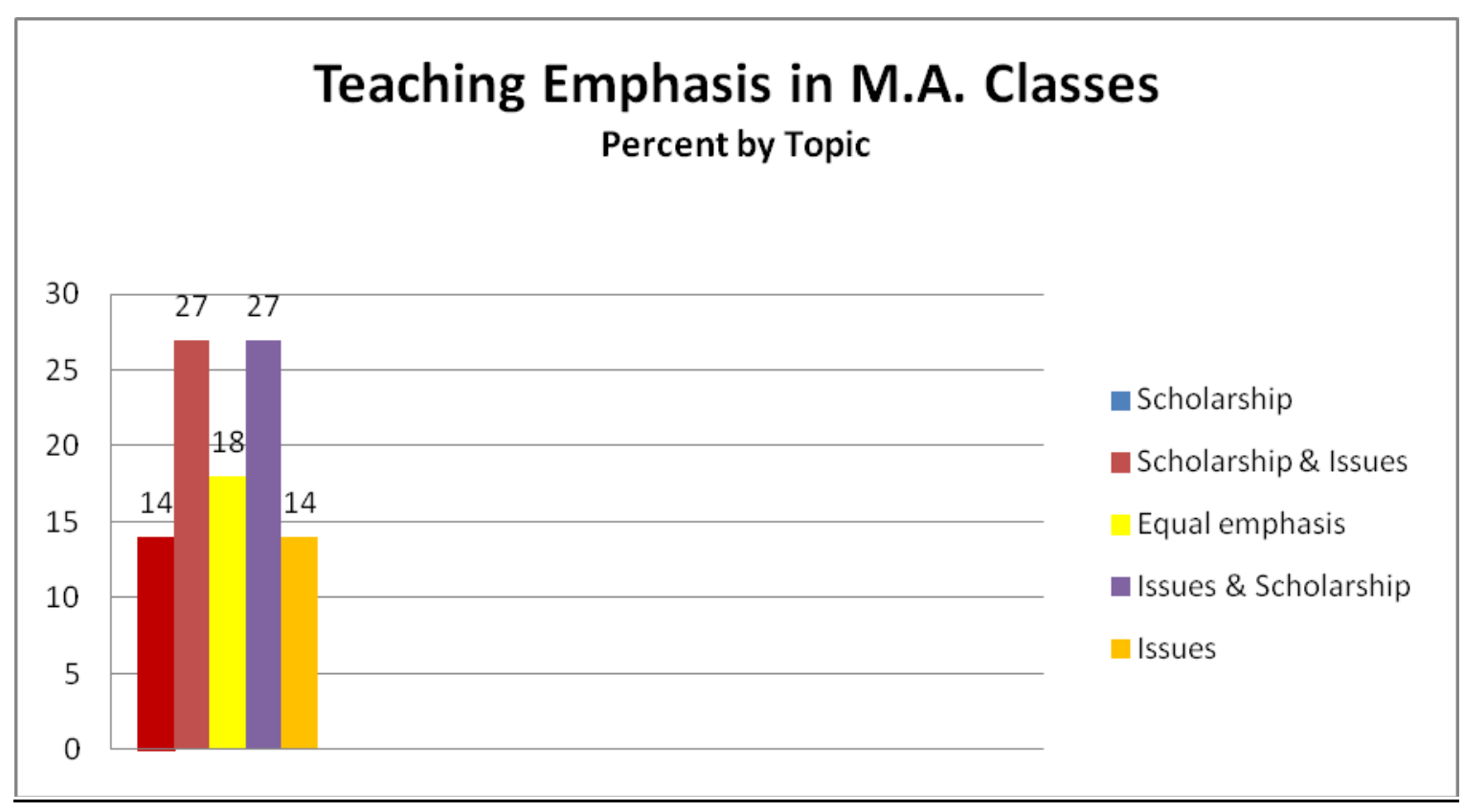

global power and wealth asymmetries in black and white terms. Given the variety of theoretical perspectives that inform the teaching of International Relations, the last thing students should do is to assume global conflict can be easily eliminated simply by building bridges internationally.

It is important to note in this brief paper that the theoretical perspectives employed by teachers of International Relations, the balance between discussing issues, paradigms, and other topics, varies widely. Data shows that differences in support for specific theories are small and that if anything, instructors take an eclectic approach in the classroom.

\section{Constructivism}

Generations around the globe, especially following the decline in popularity of Marxist classbased analysis, have learned International Relations through the theoretical lens of the Realist-Idealist dichotomy. Realists see state behavior as driven by self-interest, self-interest being defined as the acquisition and maintenance of power. The quest for power is universal and the structure of government or individual human values is largely irrelevant. Power asymmetries will inevitably lead to conflict and conquest. Idealists, on the other hand, see the state's governmental structure, political culture, and economic system as driving behavior in the world. Idealists believe that the creation of a global legal order will replace the anarchy which allows "bad" states to pursue narrow self-interest through violence and domination. There are, of course, many variations on the Idealist perspective from Wilsonianism to various strains of Neo-conservatism (Ikenberry, et. al., 2009).

Comparing and contrasting Realism and Idealism in the classroom, supplemented by the NeoRealist, Feminist, so-called Green Theory, and other perspectives, produced a straightforward 
pedagogy. In the past twenty years, however, the Constructivist perspective challenged the convention wisdom in International Relations theory. According to Ted Hopf:

The neorealist assumption of self-interest presumes to know, a priori, just what is the self being identified. In other words, the state in international politics, across time and space, is assumed to have a single eternal meaning. Constructivism instead assumes that the selves, or identities of states are a variable, they likely depend on historical, cultural, political, and social context (Hopf, 1998, p. 176).

National identity remains central to the Constructivist's explanation of the foreign policy process:

Identities are necessary, in international politics and domestic society alike, in order to ensure at least some minimal level of predictability and order . . . states require intersubjective identities that are sufficiently stable to ensure predictable patterns of behavior. A world without identities is a world of chaos, a world of pervasive and irremediable uncertainty, a world much more dangerous than anarchy. Identities perform three necessary functions in a society: they tell you and others who you are and they tell you who others are. In telling you who you are, identities strongly imply a particular set of interests or preferences with respect to choices of acting in particular domains, and with respect to particular actors (Hopf, 1998, p.17).

State support for multilateral intervention in support of human rights provides an example of how identity, socialization, and values may influence the policy process in individual nations. Overall, $70 \%$ of those polled in the United States responded positively to the question "Do you think the UN SHOULD OR SHOULD NOT actively promote human rights in member states?" This level of support was exactly at the average of all nations polled. When asked, on the other hand, "Do you think the UN should make efforts to further the rights of women or do you think this is improper interference in a country's internal affairs?", 59\% of respondents from the United States agreed. This level of support was below the global average of $66 \%$ and significantly lower than France at $74 \%$, Mexico at $88 \%$, and China at $86 \%$. The lowest levels of support for intervention in defense of women's rights was found in Egypt at 30\% and India at $48 \%$. In the area of free expression, $49 \%$ of Egyptians, 39\% of Britons, but only 13\% of those polled in the United States felt that their government should limit discussion of religious and political topics (Council on Foreign Relations, 2011).

Constructivists, in rejecting the Realists' determinism while retaining a state-centric model of the global system, emphasize the role of ideas and individual identity in shaping state preferences and international outcomes. The Constructivist perspective, therefore, should be of interest to those making the argument that study abroad can improve the world by changing students. Arguing that "the world is what we make it," Constructivists indirectly elevate the intercultural skills and understanding of other cultures and nations that forms part of study abroad's learning goals. Given that Constructivism is embraced by scholars around the world, is it wise to dismiss, as Long does, 
disciplines such as International Relations as part of a "homeland perspective?" ${ }^{1}$ Rather, does it not make more sense to value traditional academic fields which are global in their own right today and have already addressed many of the intellectual and methodological challenges which only recently have become part of the debate over study abroad curriculum and learning goals? Learning the disciplinary tools of the trade are crucial as undergraduate research abroad has grown in importance and come to be seen as an antidote to the preoccupation with experience for its own sake and personal reflection rather than scholarly analysis. Drawing upon the Constructivist perspective, for instance, allows students to generate researchable questions about knowledge gained through study abroad, questions relevant to the International Relations classroom on the home campus. Students may design a research project asking, for example, if globally-experienced and educated students are more likely to lobby the United States Senate to ratify international climate change treaties at the expense of domestic energy interests thus challenging the Realist view that only narrowly defined self-interest counts in the foreign policy process.

\section{Cosmopolitanism}

Just as international educators ask "intercultural competency to what end?", International Relations instructors, in embracing the Constructivist view that individual human volition drives state behavior, often introduce normative questions into the classroom discussion. Some believe that Cosmopolitanism can foster tolerance and recognition of universal human needs and rights as a replacement for the Hobbesian world of "war of all against all." ${ }^{2}$ In Robert Fine's view, Cosmopolitan social theory "reconstructs the history and traditions of social theory in terms of its universalistic concept of society, the recognition of differences within a universalistic frame, and the critique of methodological and political nationalism. It stands firm against approaches to understanding and changing society grounded in nationalist, racist, sexist or anti-Semitic presuppositions" (Fine, 2007, x.).

One example of cosmopolitanism's interest to the International Relations scholarly community is Richard Beardsworth's Cosmopolitanism and International Relations Theory. Beardsworth argues that while cosmopolitanism is primarily a moral theory framing what should be the case in today's world, it also generates questions that can be satisfied by empirical research. Using the example of the Stockholm Convention on persistent organic pollutants, for instance, Cosmopolitanism questions the Realist assertion that building international law and enforcement regimes is futile in the face of

${ }^{1}$ This is not to dismiss the important argument that all curriculum is culture-bound and the product of a specific historical period and political economy. That is a discussion beyond the scope of this paper.

${ }^{2}$ Theodore Long, along with Michael Woolf and others, is on the right track by including Cosmopolitanism in the discussion of study abroad pedagogy. See Michael Woolf, "The Challenge of Cosmopolitanism," Cosmopolitanism and Diversity, Anthony Griswold and Michael Woolf, eds., CAPA Occasional Papers, No. 2 (May 2013), 20-28. 
global anarchy. Recognition of the common human need for a safe environment will prevail, a moral consensus will be built, and veto coalitions of self-interested nations will be overcome.

Many International Relations scholars would not necessarily agree that Cosmopolitanism will produce plural cultural identities which will replace "singular identities considered the norm" (Long, 2013, p. 31). Cosmopolitanism as understood by many in the International Relations field acknowledges that individuals "come from somewhere" and are not in any formal way citizens of a political entity beyond the national nor likely to become one anytime soon. At the same time, Cosmopolitans recognize that common natural rights do exist and that cultural relativism is no excuse for crimes against humanity. A Cosmopolitan, exposed in the International Relations classroom to a discussion of how global norms can become embedded in a national culture, might support the new thinking about national sovereignty and human rights seen in the United Nation's embrace of the interventionist Responsibility to Protect principle. Finally Cosmopolitanism revives the admonition to "think global, act local" which reinforces the popular goal on some campuses in the United States of linking international study to domestic local communities and social challenges (Slimbach, 2010).

\section{The Study Abroad Connection}

The field of International Relations provides a variety of theories and tools to prepare students for overseas educational and co-curricular activities and to help them process and apply what they have learned abroad when they return to the home campus. Realism exposes students to the world of self-interest, disruptions to the balance of power, and anarchy which informs the world view of many policy-makers. Idealism, with its emphasis on law, regime creation, and building understanding among democratic states is custom made for study abroad proponents. At the same time, Wilsonianism and other variations of Idealism, provides a definition of democracy and its links to international peace which are based on specific economic and political structures. With Idealism, of course, much blood can be shed to change states which do not conform to the prescribed formula of democratic capitalism. Constructivism, on the other hand, is neither deterministic nor culturebound and holds out the possibility that people can change. This change, needless to say, can be for good or evil. Consider the concept of "failed states" and the mayhem which may result when a powerful state attempts to fix the problem. Here is what one member of George H. Bush's administration said, dismissing what he called the "reality-based community": "We are an empire now, and when we act, we create our own reality. And while you're studying that reality--judiciously as you will--we'll act again, creating other new realities, which you can study too, and that's how things will sort out. We're history's actors ...” (Brzezinski, 2007, p. 137).

The Constructivist notion that "things are what we make them" has been criticized for being imperialism in idealist clothing and has led to several variations including Moral Constructivism and calls to construct a global civil society. David Chandler in arguing for the potential of Constructivism to promote a moral global civil society says:

Constructivism is the broadest and most mainstream approach of global civil 
society theorising, which sees morality constraining power through

new mechanisms of international interaction, whereby non-state actors pressurise states to act in more morally-enlightened manner.

Constructivists argue that states, especially Western states, have

redefined or reconstructed their identities and interests, becoming part

of a new post-Westphalian moral agenda (Chandler, 2004, p. 19).

While there are varying levels of comfort among faculty in including questions of ethics, morality, and values in the International Relations classrooms, the topic tends to emerge in any event through student's questions if nowhere else. Of course faculty and administrators have a normative agenda, acknowledged or subconscious. Many of us are drawn to education with a hope of righting the world's wrongs. The challenge is to reconcile our normative concerns with our primary obligation as teachers and scholars to prize objectivity, seek counter-factual evidence to test our findings, and let the reader come to their own conclusions about the social implications of our work. The stated goal of some study abroad programs and educators of preparation for global citizenship and pursuit of global peace and understanding, as well as an emphasis on personal development which Michael Woolf calls the promise of "mystical transformation," may reduce the value of what should be a profound academic experience (Woolf, 2010; Ogden, 2007-08; and Reilly \& Senders, 2009). The key is for students to be exposed to Realism, Idealism, Constructivism, and other theoretical perspectives that form the ever-evolving International Relations canon so that they make informed decisions about global norms and ethics.

If Constructivism opens students minds to the possibility that "the world is what we make it," then Cosmopolitanism can help provide a moral compass to guide the establishment of this new order. At the end of the day, most teachers of International Relations do not cling to a narrow theoretical bias when it comes to understanding human behavior on the world stage. Adding Cosmopolitanism to the mix, with its appreciation of both the positive tribal dimensions of nationalism and the recognition of universal human norms, can bring out the best in students as they take in the wider world through study abroad.

\section{Conclusion}

The professionals in the international education field have provided a vast array of overseas opportunities ranging from traditional direct enrollment in the world's great universities to deep immersion through community-based learning in states facing economic, social, and political challenges. The Forum on Education Abroad, recognized by the U.S. Department of Justice and the Federal Trade Commission as the Standards Development Organization (SDO) for the field of education abroad, suggests that programs foster "the integration of student learning abroad with requirements and learning at the home institution and regularly evaluates its success in this area" (Forum on Education Abroad, 2011, p. 10). Given this standard, international educational programs 
need to ensure that both the content of courses and the marketing of study abroad are consistent with the generally accepted concepts, methods of enquiry, and pedagogy in a given academic field. This requirement is certainly relevant for the field of International Relations since many majors study abroad and many more students take International Relations courses to prepare for an overseas learning experience. An important factor in ensuring that the overseas curriculum meets the disciplinary and academic needs of the home campus is greater faculty involvement in study abroad.

Collaboration between study abroad professionals and faculty differs greatly among schools in the United States. In some campuses faculty are involved in every step of program planning, implementation, and assessment. Many schools provide faculty with opportunities to teach abroad. At other institutions the study abroad office operates in isolation from academic departments with overworked staff struggling to administer every aspect of the processes from recruitment to risk management. Given the wide disparities in faculty involvement and assignment of study abroad administrative duties, the following steps can be considered a minimum to promote the curriculum integration mandated by the Forum on Education Abroad and longed for by faculty at home and abroad:

- involve faculty in overall study abroad program design

- encourage faculty to include material in their courses to prepare students for study abroad

- consult with faculty from specific disciplines to assess courses offered abroad

- develop collegial relations between colleagues and study abroad professionals at overseas programs

- Establish two-way program visits which promote collaboration between domestic and overseas faculty on curriculum, scholarship, and student development

Theodore Long's call for replacing of homeland curriculum, which he assumes is rooted in discrete cultures not the product of a world-wide evolutionary process predating globalization by centuries, runs counter to the call for further curriculum integration. Study abroad supporters sometimes forget that most of the subject matter, including normative questions, is already well covered by the humanities, natural sciences, and social sciences. There is certainly nothing wrong with providing an integrative seminar or capstone experience to enhance student learning and personal reflection while abroad. Many programs have been doing this for years. Replacing study abroad with a discrete global studies curriculum, on the other hand, will only prevent students who need to satisfy core curriculum and major requirements from taking part (Long, 2013, p. 34). First and foremost, an international education experience must be rooted in the disciplinary subjects and graduation requirements that faculty teach every day.

I am quite willing to trust my colleagues abroad in the International Relations classroom, be it in Chile, Cape Town, or Paris, to expose students to a critique of the contemporary global system. It is also quite likely that they will include a normative dimension be it informed by Cosmopolitanism, Neo-Marxism, or some imagined concept of global citizenship. What I need to be assured of is that they are also conducting relevant research and covering the basics of the discipline in the classroom. 
In order to do this, I need knowledge of and interaction with colleagues abroad, not the availability of more study abroad programs which claim to offer a globalized curriculum with a specific normative agenda. For many International Relations faculty, we could use a lot less of the preaching to the choir about the value of an overseas experience and a bit more assurance that specific learning objectives have been met which will further students' growth as scholars. If we help students improve their analytical skills and provide them real opportunities for field observation abroad, I am confident that most young people will do quite well charting their own moral path through the complexities of globalization.

\section{References}

Albright, Shari Becker, "Global Competence in K-12 Education," presented to the 2012 National Association of Foreign Student Advisors conference, (May 2012), http://www.nafsa.org/_/File/_/colloquium12_shari_albright.pdf

Beardsworth, Richard, Cosmopolitanism and International Relations Theory. Cambridge, England: Polity, 2011.

Brzezinski, Zbigniew, Second Chance: Three Presidents and the Crisis of American Superpower. New York: Basic Books, 2007.

Chalmers, William D, “The Great American Passport Myth: Why Just 3.5\% Of Us Travel Overseas!," Huffington Post (9/29/12), http://www.huffingtonpost.com/william-d-chalmers/thegreat-american-passpo_b_1920287.html.

Chandler, David, Constructing Global Civil Society: Morality and Power in International Relations. New York: Palgrave McMillian, 2004.

Council on Foreign Relations, Public Opinion on Global Issues, December 2011 www.cfr.org/publicopinion

Deardorff, Darla K., “Theory Reflections: Intercultural Competence Framework/Model,” (2006), http://www.nafsa.org/_file/_theory_connections_intercultural_competence.pdf

Fine, Robert, Cosmopolitanism. New York: Routledge, 2007.

Forum on Education Abroad, Standards of Good Practice for Education Abroad, 4th Edition (2011). Hopf, Ted, "The Promise of Constructivism in International Relations Theory." International Security, Vol. 23, No. 1 (Summer 1998), 171-200.

Ikenberry, John G., et al., The Crisis of American Foreign Policy: Wilsonianism in the Twenty-First Century. Princeton: Princeton University Press, 2009.

Institute of International Education, Open Doors. 2013

Long, Theodore E., "From Study Abroad to Global Studies: Reconstructing International Education for a Globalized World." Frontiers: The Interdisciplinary Journal of Study Abroad, 22 (Winter 2012-Spring 2013), 25-36.

Maliniak, Daniel, et al. TRIP Around the World: Teaching, Research, and Policy Views of International Relations Faculty in 20 Countries. Williamsburg, Virginia: The Institute for the Theory and Practice of International Relations at the College of William and Mary, 2012.

National Center for Education Statistics, "Digest of Education Statistics: 2012, Table 3" http://nces.ed.gov/programs/digest/d12/tables/dt12_003.asp?referrer=report. 
Ogden, Anthony, "The View from the Veranda," Frontiers: The Interdisciplinary Journal of Study Abroad, 15 (Winter 2007- Spring 2008), 35-56.

Slimbach, Richard, Becoming World Wise: A Guide to Global Learning. Sterling, Virginia: Stylus, 2010.

Reilly, Doug and Stefan Senders, "Becoming the Change We Want to See: Critical Study Abroad for a Tumultuous World," Frontiers: The Interdisciplinary Journal of Study Abroad, 18 (Fall 2009), 241-267.

West, Charlotte, “Toward Globally Competent Pedagogy,” National Association of Foreign Student Advisors, 2012.

http://www.nafsa.org/uploadedFiles/Chez_NAFSA/Find_Resources/Publications/Periodicals/Ep ublications/epub_toward_globally.pdf, 2012.

Woolf, Michael, "Another 'Mishegas': Global Citizenship," Frontiers: The Interdisciplinary Journal of Study Abroad, 19 (Fall-Winter 2010), 47-60.

Woolf, Michael, "(Un) Original Sin," presented to the annual meeting of the Association of International Education Administrators, (February 20-23, 2010).

Woolf, Michael, "The Challenge of Cosmopolitanism," in Cosmopolitanism and Diversity, Anthony Griswold and Michael Woolf, eds., CAPA Occasional Papers, No. 2 (May 2013), 20-28. 